\title{
Intraspecific Genomic Variation Within Xanthomonas albilineans, the Sugarcane Leaf Scald Pathogen
}

\author{
M. J. Davis, P. Rott, C. J. Warmuth, M. Chatenet, and P. Baudin
}

\begin{abstract}
First and third authors: Tropical Research and Education Center, University of Florida, IFAS, 18905 S.W. 280 Street, Homestead 33031; and second, fourth, and fifth authors: Centre de Coopération Internationale en Recherche Agronomique pour le Développement, CIRAD-CA, UR PHYMA, BP 5035, 34032 Montpellier Cedex, France.
\end{abstract} Accepted for publication 25 November 1996.

\begin{abstract}
Davis, M. J., Rott, P., Warmuth, C. J., Chatenet, M., and Baudin, P. 1997. Intraspecific genomic variation within Xanthomonas albilineans, the sugarcane leaf scald pathogen. Phytopathology 87:316-324.

To better understand the nature of recent outbreaks of leaf scald disease of sugarcane in a number of sugarcane production regions of the world including Florida, Guadeloupe, Louisiana, Mauritius, Taiwan, and Texas, a study of the worldwide genetic variation of the pathogen was undertaken. A total of 218 strains from 31 geographic locations were examined. Genomic DNA of each strain was digested with the rare cutting restriction enzyme SpeI, and the fragments were separated by pulsed-field gel electrophoresis (PFGE). A total of 102 bands were identified, and 54 different DNA banding patterns (haplotypes) were observed. Eight groups of banding patterns, designated PFGE groups A through $\mathrm{H}$, were consistently detected by visual, principal component, and cluster analyses. Five groups were comprised of multiple haplotypes

attributed to the introduction of strains belonging to PFGE group B. When infection by two strains each of the newly introduced strains (PFGE group B) and those previously present in Florida (PFGE group A) was analyzed in 22 sugarcane cultivars by reisolation 24 weeks after inoculation, a significantly greater mean frequency was detected for PFGE group B strains and no cultivar by PFGE group interaction was observed. Inadvertent dispersal of the pathogen among plants, possibly by means of aerosols or splashing water, was detected in a subsequent experiment. Strains of PFGE group B were recovered from the internal tissues of some plants inoculated with PFGE group A strains and were also found to be epiphytic colonizers of nonsymptomatic, noninoculated plants adjacent to the inoculated plants; whereas strains of PFGE group A were recovered only from plants that had been inoculated with them. Thus, the possibility became more apparent that strain variation might be associated, at least in part, with factors governing plant-to-plant spread of the pathogen in nature.
\end{abstract} representing numerous strains, and three were comprised of single haplotypes representing one strain each. The leaf scald outbreaks in Florida, Louisiana, Texas, and possibly Guadeloupe and Taiwan could be
Additional keywords: DNA fingerprint, epidemiology, quarantine regulations.
Leaf scald, a bacterial vascular disease of sugarcane caused by Xanthomonas albilineans, is one of the major diseases of sugarcane $(23,28,31)$. It was first recorded in Australia in 1911 by North, but strong presumptive evidence exists that the disease was prevalent in the Fiji Islands by 1908, if not earlier (23). The cause of the disease was independently discovered and later described in the 1920s by Wilbrink (41) in Java and North (24) in Australia and Fiji. Soon after being described, the disease was found in the Philippines, Mauritius, and Hawaii (23). By 1961, leaf scald had been identified in 22 sugarcane-producing countries (23) and, by 1994, in 58 different geographic locations (32). Recently, the occurrence and incidence of the disease has increased at an alarming rate in some areas including Florida (8), Guadeloupe (33), Guatemala (25), Louisiana $(15,18)$, Mauritius (4), Mexico (19), Taiwan (6), and Texas (20), causing considerable concern that it will become a limiting factor in sugarcane production and variety development in these regions.

The outbreaks of leaf scald in Guatemala, Louisiana, Mexico, and Texas were the first occurrence of the disease in these areas and, therefore, could be attributed to pathogen introduction. However, in areas such as Florida and Mauritius, the disease had been endemic for many years prior to the recent outbreaks, and the explanation for the outbreaks was unknown. New variants of the pathogen, arising either through mutation of established strains or

Corresponding author: M. J. Davis; E-mail address: mjd@gnv.ifas.ufl.edu

Publication no. P-1997-0124-02R

(C) 1997 The American Phytopathological Society the introduction of exotic strains, might have been responsible in some situations. However, other factors cannot be disregarded as possible explanations, such as the production of more susceptible cultivars as found in Guadeloupe (34).

Leaf scald outbreaks have been disruptive and costly (18). In addition to the yield reductions incurred in commercial production, replacement of susceptible cultivars with more resistant cultivars has often been necessary. Consequently, the burden on cultivar development programs has increased because of the loss of susceptible breeding lines, the implementation of more stringent procedure to screen for resistance, and the need to fill the void left after the untimely demise of cultivars that had taken years to develop (7).

If the introduction of exotic strains of $X$. albilineans has lead to outbreaks of leaf scald in regions where the disease is already endemic, then pathologically significant intraspecific variation must exist between resident and exotic strains. Variation in virulence of the pathogen is suggested by differences in cultivar reactions from one country to another and also within the same location $(2,8,22$, 26,37). Evidence for the differential reaction of sugarcane cultivars to strains of the pathogen was observed in Mauritius, suggesting the existence of distinct races of the pathogen (3). Following the recent outbreaks in Mauritius (4), Guadeloupe (21), and Florida (M. J. Davis, unpublished data), the apparent spread of $X$. albilineans by aerial means, unlike the usual dissemination by mechanical means, was encountered, suggesting that differences in transmissibility might also be associated with intraspecific variation. Unequivocal evidence for the existence of highly structured differences within populations of the pathogen, however, has not been obtained experimentally. The reasons for this include the inability to identify strains repre- 
sentative of variant populations, variability in virulence within populations of the pathogen, imprecise inoculation methods, and variability in host reaction due, in part, to latent infections.

Efforts have been made to find physiological or biochemical properties indicative of significant population structure within $X$. albilineans. Strains of $X$. albilineans are very homogenous in respect to biochemical and physiological characteristics and constitute a well-delineated species $(39,40,42)$, but variation among strains has been found in colony and cell morphology (28), wholecell proteins (42), fatty acid methyl-esters (FAME) (42), bacteriophage reaction (30), antibody reaction $(1,30)$, and DNA fingerprints (1). Lysotypical and serological properties and protein profiles correlated somewhat with one another and with the geographic origin of strains $(30,42)$. However, serological, protein, and FAME properties were the same for strains of $X$. albilineans isolated in Florida before and after the recent leaf scald outbreak $(32,42)$ and, therefore, provided no evidence for pathogen variation being responsible for the outbreak. Recently, however, differences between old and new strains from Florida and other strains were obtained for monoclonal antibody reaction patterns and for DNA fingerprints obtained by EcoRI digestion of genomic DNA (1), indicating that these or similar methods might be useful for characterizing intraspecific variation within $X$. albilineans.

Genomic DNA fingerprinting by pulsed-field gel electrophoresis (PFGE) of large DNA fragments generated by digestion of DNA with restriction endonucleases that recognize infrequently occurring sites has proven to be a powerful means to differentiate bacterial types. It has been useful for differentiating closely related strains of $X$. campestris causing diseases of citrus (12), characterization of Burkholderia solanacearum from several crop plants in the French West Indies (13), and in epidemiological studies of human and animal pathogens $(5,14,17,27,35)$. In the present study, the technique was utilized to investigate the possibility of intraspecific genetic variation of $X$. albilineans in Florida in relationship to the recent outbreak of leaf scald disease. Two distinct variants were identified among strains from Florida, and their spatial and temporal distribution strongly suggested that the outbreak was likely caused by the introduction of one of the variants (9). The study was then extended to investigate genetic variation of the pathogen on a worldwide basis and examine pathological differences among variants.

\section{MATERIALS AND METHODS}

Bacterial strains. Strains of $X$. albilineans used in this study are listed in Table 1. Strains were grown in culture at $28^{\circ} \mathrm{C}$ on a modified Wilbrink's (MW) medium (10). Serological characterization of strains was conducted in this or previous studies as described by Rott et al. (32).

DNA analysis. The methods for restriction endonuclease analysis were similar to those described by Egel et al. (12). Cells were removed from MW medium, washed in $1 \mathrm{ml}$ of SE buffer $(75 \mathrm{mM}$ $\mathrm{NaCl}$ and $25 \mathrm{mM}$ EDTA, $\mathrm{pH} 8.0)$, and resuspended at $1 \times 10^{9}$ $\mathrm{CFU} / \mathrm{ml}$ in $0.5 \mathrm{ml}$ of SE buffer. The cell suspension was mixed with $0.5 \mathrm{ml}$ of molten $\left(37^{\circ} \mathrm{C}\right)$, low-melting-point agarose solution (10 mM Tris, pH 8.0; $10 \mathrm{mM} \mathrm{MgCl}_{2} ; 10 \mathrm{mM}$ EDTA, pH 8.0; $1.5 \%$ [wt/vol] InCert agarose [FMC BioProducts, Rockland, ME]) and pipetted into a plastic plug mold (Bio-Rad Laboratories, Richmond, CA). The mold was then placed at $4{ }^{\circ} \mathrm{C}$ for 10 to 15 min to harden the plugs. The plugs were transferred to $2 \mathrm{ml}$ of lysing solution $(2 \mathrm{mg} / \mathrm{ml}$ proteinase $\mathrm{K} ; 1 \% \mathrm{wt} / \mathrm{vol} N$-lauryl Sarkosyl; and $0.5 \mathrm{mM}$ EDTA, $\mathrm{pH} 9.5$ ) and incubated at $50^{\circ} \mathrm{C}$ for 48 to $72 \mathrm{~h}$ to allow cell lysis. After lysis, the plugs were transferred to 2 $\mathrm{ml}$ of sterile TE (10 mM Tris and $1 \mathrm{mM}$ EDTA, $\mathrm{pH}$ 7.5) and incubated for $15 \mathrm{~min}$ at room temperature. The plugs were incubated for an additional 6 to $8 \mathrm{~h}$ at room temperature in fresh TE, trans-

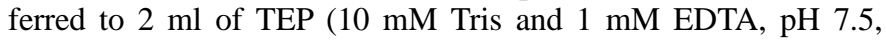
containing $10 \mu \mathrm{l} / \mathrm{ml}$ of PMSF solution [100 mM phenylmethylsul- fonyl fluoride in isopropyl alcohol stored at $\left.-20^{\circ} \mathrm{C}\right]$ ), and incubated at $37^{\circ} \mathrm{C}$ for $2 \mathrm{~h}$. The plugs were transferred to fresh TEP buffer and incubated at $4^{\circ} \mathrm{C}$ at least overnight.

For restriction endonuclease digestion, a $5 \times 5 \times 1$-mm piece was cut from a plug, placed in TE, and incubated at $37^{\circ} \mathrm{C}$ for $2 \mathrm{~h}$. The TE was replaced with $200 \mu \mathrm{l}$ of restriction buffer (buffer B; Promega Corp., Madison, WI), and the plug was incubated for $2 \mathrm{~h}$ on ice. The restriction buffer was replaced with $200 \mu \mathrm{l}$ of fresh restriction buffer containing $0.01 \mathrm{mg} / \mathrm{ml}$ of acetylated bovine serum albumin and $18 \mathrm{U}$ of SpeI (Promega Corp.). The plug was incubated from $8 \mathrm{~h}$ to overnight at $37^{\circ} \mathrm{C}$. The restriction buffer was then replaced with $500 \mu \mathrm{l}$ of ES (0.5 mM EDTA, pH 8.0, and $1 \%$ [wt/vol] $N$-lauryl Sarkosyl), and the plug was incubated at $50^{\circ} \mathrm{C}$ for $2 \mathrm{~h}$. The ES was then replaced with ESP (ES containing $1 \mathrm{mg} / \mathrm{ml}$ of proteinase $\mathrm{K}$ ), and the plug was stored at $4^{\circ} \mathrm{C}$.

Before electrophoresis, a portion of plug $(2.5 \times 5 \times 1 \mathrm{~mm})$ for each sample to be analyzed was soaked at room temperature for 30 $\mathrm{min}$ in TE, $\mathrm{pH} 7.5$, and for $15 \mathrm{~min}$ in $0.5 \times \mathrm{TBE}$ (45 mM Tris; 45 $\mathrm{mM}$ boric acid; and $1 \mathrm{mM}$ EDTA, $\mathrm{pH}$ 8.0) and inserted into an individual well of a $1 \%$ FastLane agarose (FMC BioProducts) gel in $0.5 \times$ TBE. PFGE in $0.5 \times$ TBE was conducted at $200 \mathrm{~V}(16 \mathrm{~V} / \mathrm{cm}$ of gel) in a CHEF DR II unit (Bio-Rad Laboratories). The pulse times were $4 \mathrm{~s}$ for $0.5 \mathrm{~h}$, and then increasing linearly from 10 to $40 \mathrm{~s}$ for $20 \mathrm{~h}$. ProMega-Markers Lambda Ladders (Promega Corp.) were used as molecular markers. Gels were stained in $0.5 \mathrm{mg} / \mathrm{liter}$ of ethidium bromide and photographed with ultraviolet transillumination using type 55 Polaroid film (Polaroid Corp., Cambridge, MA).

Data analysis. Based on visual inspection of DNA banding profiles, strains were assigned to haplotypes (distinct DNA fingerprints), and strains representing each haplotype were selected for side-by-side measurement of DNA fragment sizes. Photographic images of DNA fingerprints and molecular weight markers in each gel were recorded using a CCD camera (model I RGB; Microimage Video Systems Co., Boyertown, PA) and Optimus image analysis software (BioScan, Inc., Edmonds, WA), and the molecular weight of each DNA band was measured using the 1-D Biomed computer program (Advanced American Biotechnology, Fullerton, CA). To compensate for experimental error in molecular weight determinations, the inclusive range of molecular masses of all DNA fragments from 20 to $550 \mathrm{~kb}$ was divided into 5 -kb fixed intervals, each DNA band was assigned to an interval based on estimated molecular mass, and bands within each interval were considered to be identical. Binary scores based on the presence or absence of DNA bands were used to calculate the pairwise similarity among banding patterns using the Dice coincidence index (11) (Rapdistance Programs, version 1.03, for the analysis of patterns of RAPD fragments; Australian National University, Canberra, Australia) as follows: similarity between paired haplotypes $\left(S_{x y}\right)$ was the number of common bands in both DNA profiles $\left(n_{x y}\right)$ divided by the average number of bands for the two haplotypes $\left[S_{x y}=2 n_{x y} /\left(n_{x}+n_{y}\right)\right]$. Dissimilarity or distance between haplotypes $\left(D_{x y}\right)$ was 1 minus the similarity $\left(D_{x y}=1-S_{x y}\right)$. Principal component analysis of the similarity matrix was conducted using the Princomp and G3D procedures of the SAS computer program version 6.11 (SAS Institute, Cary, NC). Cluster analysis of the distance matrix was conducted by the unweighted pair group method with arithmetic means (UPGMA) (36) using the Cluster procedure (SAS Institute) and the Neighbor procedure of the PHYLIP version 3.5c computer program (PHYLIP, version 3.5c; Department of Genetics, University of Washington, Seattle). To evaluate the robustness of the groupings obtained by cluster analysis, the binary data were subjected to bootstrap analysis using the Winboot computer program (International Rice Research Institute, Manila, Philippines). Bootstrap values were calculated as the frequency with which a particular group appears among 1,000 dendrograms constructed by bootstrapping.

Plant material. Stalks of apparently healthy plants of sugarcane cultivars CP 53-1, CP 63-588, CP 70-1133, CP 72-1210, CP 


\begin{tabular}{|c|c|c|c|c|c|c|c|c|}
\hline Strain & Culture collection ${ }^{\mathrm{a}}$ & Origin & $\begin{array}{c}\text { Date of } \\
\text { origin }\end{array}$ & Contributor & $\begin{array}{l}\text { PFGE }^{b} \\
\text { group }\end{array}$ & Serovar $^{c}$ & $\begin{array}{l}\text { Protein } \\
\text { cluster }^{\mathrm{d}}\end{array}$ & $\begin{array}{l}\text { FAME }^{\mathrm{e}} \\
\text { group }^{\mathrm{d}}\end{array}$ \\
\hline AUS-022A & CCBP (UQM 868) & Australia & & A. C. Hayward & A-01 & 1 & 1 & 3 \\
\hline AUS-020A & CCBP (UQM 866) & Australia & & A. C. Hayward & A-01 & 1 & 1 & 1 \\
\hline AUS-023A & CCBP (UQM 869) & Australia & & A. C. Hayward & A-01 & 1 & 1 & 1 \\
\hline AUS-024A & CCBP (UQM 870) & Australia & & A. C. Hayward & A-01 & 1 & 1 & 3 \\
\hline AUS-025A & CCBP (UQM 875) & Australia & & A. C. Hayward & A-01 & 1 & 1 & 3 \\
\hline AUS-098A & $\mathrm{CCBP}$ & Australia & 1992 & P. Taylor & A-01 & 1 & & \\
\hline AUS-099A & CCBP & Australia & 1992 & P. Taylor & A-01 & 1 & & \\
\hline BLZ-102A & CCBP & Belize & 1992 & P. Rott & B-10 & 1 & & \\
\hline BLZ-103A & CCBP & Belize & 1992 & P. Rott & B-15 & 1 & & \\
\hline BLZ-104A & CCBP & Belize & 1992 & P. Rott & B-13 & 1 & & \\
\hline BLZ-105A & CCBP & Belize & 1992 & P. Rott & B-19 & 1 & & \\
\hline BRA-049A & CCBP & Brazil & 1981 & J. Rodrigues Neto & B-21 & 1 & & \\
\hline BRA-050A & CCBP & Brazil & 1988 & J. Rodrigues Neto & B-13 & 1 & & \\
\hline BRA-051A & CCBP & Brazil & 1988 & J. Rodrigues Neto & B-09 & 1 & 1 & 1 \\
\hline BRA-114 & CCBP & Brazil & 1993 & C. O. N. Cardoso & B-12 & 1 & & \\
\hline BRA-115 & CCBP & Brazil & 1993 & C. O. N. Cardoso & B-11 & 3 & & \\
\hline BRA-116A & CCBP & Brazil & 1993 & C. O. N. Cardoso & B-20 & 1 & & \\
\hline BRA-117A & CCBP & Brazil & 1993 & C. O. N. Cardoso & B-16 & 1 & & \\
\hline BRA-118A & CCBP & Brazil & 1993 & C. O. N. Cardoso & B-10 & 1 & & \\
\hline BRA-119A & CCBP & Brazil & 1993 & C. O. N. Cardoso & B-14 & 1 & & \\
\hline BRA-120A & CCBP & Brazil & 1993 & C. O. N. Cardoso & B-21 & 1 & & \\
\hline BRA-121A & CCBP & Brazil & 1993 & C. O. N. Cardoso & B-09 & 1 & & \\
\hline BRA-122A & CCBP & Brazil & 1993 & C. O. N. Cardoso & B-06 & 3 & & \\
\hline BRA-123A & CCBP & Brazil & 1993 & C. O. N. Cardoso & B-07 & 3 & & \\
\hline BRB-034A & CCBP & Barbados & 1985 & M. Chatenet & B-01 & 1 & & \\
\hline BRB-075A & CCBP (NCPPB 2249) & Barbados & 1968 & J. F. Bradbury & B-01 & 1 & 1 & 2 \\
\hline BRB-076A & CCBP (NCPPB 2257) & Barbados & 1969 & D. C. Harris & A-01 & 1 & 1 & 1 \\
\hline BRB-101A & $\mathrm{CCBP}$ & Barbados & 1992 & P. Rott & B-01 & 1 & & \\
\hline CIV-035A & CCBP & Ivory Coast & 1986 & P. Rott & $\mathrm{C}-03$ & 2 & & \\
\hline CIV-036A & CCBP & Ivory Coast & 1986 & P. Rott & $\mathrm{C}-05$ & 2 & 2 & 1 \\
\hline CIV-039A & CCBP & Ivory Coast & 1986 & P. Rott & $\mathrm{C}-02$ & 2 & 2 & 2 \\
\hline CIV-040A & CCBP & Ivory Coast & 1986 & M. Granier & $\mathrm{C}-02$ & 2 & 2 & 2 \\
\hline CIV-042A & CCBP & Ivory Coast & 1986 & M. Granier & $\mathrm{C}-02$ & 2 & 2 & 2 \\
\hline CMR 037A & CCBP & Cameroun & 1986 & P. Rott & $\mathrm{C}-02$ & 2 & & \\
\hline CMR-011A & CCBP & Cameroun & 1983 & P. Rott & $\mathrm{C}-02$ & 2 & & \\
\hline CMR-013A & CCBP & Cameroun & 1983 & P. Rott & $\mathrm{C}-02$ & 2 & 2 & 2 \\
\hline CMR-029A & CCBP & Cameroun & 1984 & P. Rott & $\mathrm{C}-02$ & 2 & & \\
\hline CMR-041A & CCBP & Cameroun & 1986 & M. Granier & $\mathrm{C}-02$ & 2 & & \\
\hline DOM-096A & CCBP & Dominican Republic & 1991 & M. J. Davis & B-01 & 1 & & \\
\hline DOM-097A & CCBP & Dominican Republic & 1991 & M. J. Davis & A-01 & 1 & & \\
\hline FJI-079A & CCBP (NCPPB 2969) & Fiji & 1961 & D. W. Dye & E-03 & 3 & 2 & 2 \\
\hline FJI-080A & CCBP (ICMP 397) & Fiji & 1961 & D. W. Dye & E-02 & 3 & 2 & 1 \\
\hline FJI-106A & CCBP (LMG 480) & Fiji & 1961 & D. W. Dye & E-02 & 3 & & \\
\hline GLP-007A & CCBP (CFBP 1953) & Guadeloupe & & M. Chatenet & E-01 & 3 & 2 & 1 \\
\hline GLP-010A & CCBP & Guadeloupe & & J. C. Girard & B-06 & 1 & 1 & 2 \\
\hline GLP-012A & ССBP & Guadeloupe & & L. Férèol & B-01 & 1 & 1 & 2 \\
\hline GLP-018A & CCBP & Guadeloupe & & L. Férèol & B-01 & 1 & 1 & 1 \\
\hline GLP-043A & CCBP & Guadeloupe & 1987 & J. Montillet & B-01 & 1 & 1 & 1 \\
\hline GLP-044A & CCBP & Guadeloupe & 1987 & J. Montillet & B-01 & 1 & & \\
\hline GLP-045A & CCBP & Guadeloupe & 1987 & J. Montillet & B-01 & 1 & & \\
\hline GLP-046A & CCBP & Guadeloupe & 1987 & J. Montillet & B-02 & 1 & 1 & 1 \\
\hline GLP-054A & CCBP & Guadeloupe & 1988 & P. Rott & B-01 & 1 & 1 & 1 \\
\hline GLP-055A & CCBP & Guadeloupe & 1988 & P. Rott & B-01 & 1 & & \\
\hline GLP-056A & CCBP & Guadeloupe & 1988 & P. Rott & B-01 & 1 & 1 & 2 \\
\hline GLP-057A & CCBP & Guadeloupe & 1988 & P. Rott & B-01 & 1 & 1 & 1 \\
\hline GLP-059A & CCBP & Guadeloupe & 1989 & M. Granier & B-01 & 1 & & \\
\hline GLP-094A & CCBP & Guadeloupe & 1991 & P. Rott & B-06 & 1 & & \\
\hline GPE-025 & CCBP-G & Guadeloupe & 1991 & P. Rott & B-01 & 1 & & \\
\hline GPE-027 & CCBP-G & Guadeloupe & 1991 & P. Rott & B-01 & 1 & & \\
\hline GPE-031 & CCBP-G & Guadeloupe & 1991 & P. Rott & B-01 & 1 & & \\
\hline GPE-B6 & CCBP-G & Guadeloupe & 1992 & M. J. Davis & B-01 & 1 & & \\
\hline GPE-B8 & CCBP-G & Guadeloupe & 1992 & M. J. Davis & B-10 & 1 & & \\
\hline GPE-BT4 & CCBP-G & Guadeloupe & 1992 & M. J. Davis & $\mathrm{B}-01$ & 1 & & \\
\hline GPE-DB1 & CCBP-G & Guadeloupe & 1992 & M. J. Davis & B-01 & 1 & & \\
\hline GUY-061A & CCBP (NCPPB 290) & Guyana & 1949 & P. B. Hutchinson & B-17 & 1 & & \\
\hline GUY-069A & CCBP (NCPPB 1050) & Guyana & & S. Bisessar & B-13 & 1 & 1 & 2 \\
\hline HAW-073A & CCBP (NCPPB 1830) & USA, Hawaii & 1965 & H. Koike & A-01 & 1 & & \\
\hline
\end{tabular}

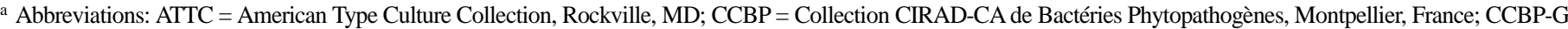
= Collection CIRAD-CA de Bactéries Phytopathogènes, Petit-Bourg, Guadeloupe, French West Indies; CFBP = Collection Française de Bactéries Phytopathogènes, Angers, France; ICMP = International Collection of Microorganisms from Plants, Auckland, New Zealand; NCPPB = National Collection of Plant Pathogenic Bacteria, Harpenden, England; UFTREC = University of Florida, Tropical Research and Education Center, Homestead; and UQM=University of Queensland, Department of Microbiology, Australia. b PFGE = pulsed-field gel electrophoresis.

c Data from Rott et al. (32) or derived as described therein.

d Data from Yang et al. (42).

e FAME = fatty acid methyl-esters. 


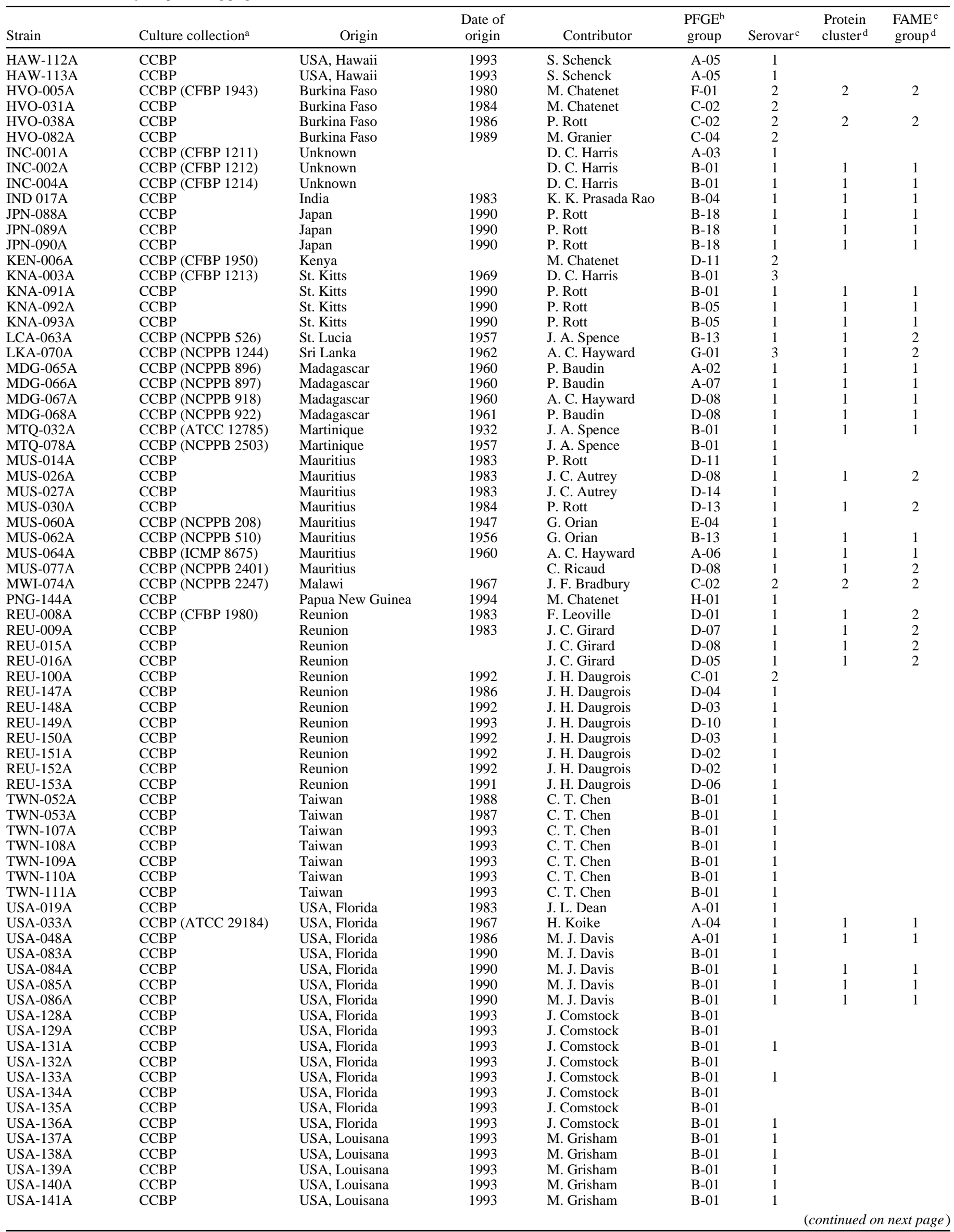




\begin{tabular}{|c|c|c|c|c|c|c|c|c|}
\hline Strain & Culture collection ${ }^{\mathrm{a}}$ & Origin & $\begin{array}{c}\text { Date of } \\
\text { origin }\end{array}$ & Contributor & $\begin{array}{l}\mathrm{PFGE}^{\mathrm{b}} \\
\text { group }\end{array}$ & Serovar ${ }^{\mathrm{c}}$ & $\begin{array}{l}\text { Protein } \\
\text { cluster }^{\mathrm{d}}\end{array}$ & $\begin{array}{l}\text { FAME }^{\mathrm{e}} \\
\text { group }^{\mathrm{d}}\end{array}$ \\
\hline USA-154A & CCBP & USA, Texas & 1994 & T. Isakeit & B-01 & 1 & & \\
\hline USA-155A & CCBP & USA, Texas & 1994 & T. Isakeit & B-01 & 1 & & \\
\hline USA-157A & CCBP & USA, Texas & 1993 & T. Isakeit & B-01 & 1 & & \\
\hline USA-158A & CCBP & USA, Texas & 1994 & T. Isakeit & B-01 & 1 & & \\
\hline USA-159A & CCBP & USA, Texas & 1994 & T. Isakeit & B-01 & 1 & & \\
\hline USA-160A & СCBP & USA, Texas & 1994 & T. Isakeit & B-01 & 1 & & \\
\hline USA-164A & ССBP & USA, Texas & 1994 & T. Isakeit & B-01 & 1 & & \\
\hline USA-165A & CCBP & USA, Texas & 1994 & T. Isakeit & B- 08 & 1 & & \\
\hline USA-166A & CCBP & USA, Texas & 1994 & T. Isakeit & B-01 & 1 & & \\
\hline USA-167A & CCBP & USA, Texas & 1993 & $\mathrm{~T}$. Isakeit & B-01 & 1 & & \\
\hline USA-168A & CCBP & USA, Texas & 1993 & T. Isakeit & B-01 & 1 & & \\
\hline USA-169A & CCBP & USA, Texas & 1993 & T. Isakeit & B-01 & 1 & & \\
\hline USA-170A & СCBP & USA, Texas & 1993 & T. Isakeit & B-01 & 1 & & \\
\hline XАCP-007 & UFTREC & USA, Florida & 1989 & M. J. Davis & B-01 & 1 & & \\
\hline XАCP-008 & UFTREC & USA, Florida & 1989 & M. J. Davis & B-03 & 1 & & \\
\hline ХАСР-009 & UFTREC & USA, Florida & 1989 & M. J. Davis & A-03 & 1 & & \\
\hline ХАCP-016 & UFTREC & USA, Florida & 1991 & M. J. Davis & B-01 & 1 & & \\
\hline ХАCP-030 & UFTREC & USA, Florida & 1991 & M. J. Davis & B-01 & 1 & & \\
\hline ХАСР-031 & UFTREC & USA, Florida & 1994 & M. J. Davis & B-01 & 1 & & \\
\hline XАCP-032 & UFTREC & USA, Florida & 1991 & M. J. Davis & B-01 & 1 & & \\
\hline XАCP-033 & UFTREC & USA, Florida & 1991 & M. J. Davis & B-01 & 1 & & \\
\hline ХАCP-057 & UFTREC & USA, Florida & 1994 & M. J. Davis & A- 03 & 1 & & \\
\hline ХАCP-067 & UFTREC & USA, Florida & 1995 & M. J. Davis & $\mathrm{A}-01$ & 1 & & \\
\hline ХАСР-068 & UFTREC & USA, Florida & 1986 & J. L. Dean & $\mathrm{A}-01$ & 1 & & \\
\hline XАCP-069 & UFTREC & USA, Florida & 1986 & J. L. Dean & A-01 & 1 & & \\
\hline ХАCP-070 & UFTREC & USA, Florida & 1986 & J. L. Dean & A-01 & 1 & & \\
\hline ХАCP-071 & UFTREC & USA, Florida & 1984 & J. L. Dean & $\mathrm{A}-01$ & 1 & & \\
\hline XACP-078D & UFTREC & USA, Florida & 1994 & J. Comstock & B-01 & & & \\
\hline ХАCP-079B & UFTREC & USA, Florida & 1994 & J. Comstock & B-01 & & & \\
\hline ХАCР-079C & UFTREC & USA, Florida & 1994 & J. Comstock & B-01 & & & \\
\hline ХАCP-080B & UFTREC & USA, Florida & 1994 & J. Comstock & B-01 & & & \\
\hline XACP-080D & UFTREC & USA, Florida & 1994 & J. Comstock & B-01 & & & \\
\hline XАCP-081B & UFTREC & USA, Florida & 1994 & J. Comstock & B-01 & & & \\
\hline XACP-081D & UFTREC & USA, Florida & 1994 & J. Comstock & B-01 & & & \\
\hline XАCP-082 & UFTREC & USA, Florida & 1994 & J. Comstock & B-01 & & & \\
\hline ХАСР-083B & UFTREC & USA, Florida & 1994 & J. Comstock & B-01 & & & \\
\hline XACP-083D & UFTREC & USA, Florida & 1994 & J. Comstock & B-01 & & & \\
\hline XACP-137D6 & UFTREC & USA, Florida & 1991 & M. J. Davis & B-01 & 1 & & \\
\hline ХАCР-C5A & UFTREC & USA, Florida & 1991 & M. J. Davis & B-01 & 1 & & \\
\hline XACP-E5R & UFTREC & USA, Florida & 1989 & M. J. Davis & $\mathrm{A}-01$ & 1 & & \\
\hline XАCP-X2A & UFTREC & USA, Florida & 1991 & M. J. Davis & B-01 & 1 & & \\
\hline XAFL-011 & UFTREC & USA, Florida & 1991 & M. J. Davis & B-01 & 1 & & \\
\hline XAFL-012 & UFTREC & USA, Florida & 1991 & M. J. Davis & B-01 & 1 & & \\
\hline XAFL-013 & UFTREC & USA, Florida & 1991 & M. J. Davis & B-01 & 1 & & \\
\hline XAFL-014 & UFTREC & USA, Florida & 1991 & M. J. Davis & B-01 & 1 & & \\
\hline XAFL-038 & UFTREC & USA, Florida & 1992 & M. J. Davis & B-01 & 1 & & \\
\hline XAFL-040 & UFTREC & USA, Florida & 1992 & M. J. Davis & B-01 & 1 & & \\
\hline XAFL-041 & UFTREC & USA, Florida & 1992 & M. J. Davis & B-01 & 1 & & \\
\hline XAFL-90-18 & UFTREC & USA, Florida & 1990 & M. J. Davis & B-01 & 1 & & \\
\hline ZAF-021A & CCBP & South Africa & & R. A. Bailey & D-11 & 1 & & \\
\hline ZAF-028A & CCBP & South Africa & & R. A. Bailey & D-12 & 1 & & \\
\hline ZAF-126A & CCBP & South Africa & 1993 & S. McFarlane & B-01 & 1 & & \\
\hline ZAR-047A & CCBP & Zaire & 1987 & M. Granier & $\mathrm{C}-02$ & 2 & 2 & 2 \\
\hline ZIM-071A & CCBP (NCPPB 1737) & Zimbabwe & 1965 & R. A. Lelliott & $\mathrm{C}-04$ & 2 & 2 & 2 \\
\hline ZIM-072A & CCBP (NCPPB 1738) & Zimbabwe & 1965 & R. A. Lelliott & C-04 & 2 & 2 & 2 \\
\hline ZIM-095A & СCBP & Zimbabwe & 1991 & P. Rott & $\mathrm{C}-03$ & 2 & & \\
\hline
\end{tabular}


72-2086, CP 75-1553, CP 77-1776, CP 78-1247, CP 78-1628, CP 80-1743, CP 80-1827, CP 81-1238, CP 81-1302, CP 81-1384, CP 84-1198, CP 85-1308, CP 85-1382, CP 86-2024, CP 89-2348, CP 89-2352, CR 74-250, and US 59-16-1 were obtained from the United States Sugarcane Field Station, Canal Point, FL. Leaf scald disease had been recently observed in commercial fields of CP 72-1210 and CP 78-1247 in Florida and of CR 74-250 in the Dominican Republic. CP 63-588, CP 70-1133, CP 72-1210, and CP 72-2086 were well-established commercial cultivars in Florida. CP 53-1, CP 89-2348, and CP 89-2352 were highly susceptible to ratoon stunting disease, but their susceptibility to leaf scald disease was unknown. CP 75-1553, CP 77-1776, CP 78-1247, CP 78-1628, CP 80-1743, CP 80-1827, CP 81-1238, CP 81-1302, CP 81-1384, CP 84-1198, CP 85-1308, CP 85-1382, and CP 86-2024 were cultivars that either had been recently released for commercial production in Florida or were being considered for release. Of these latter cultivars, CP 75-1553 and CP 80-1827 had had a relatively high percentage of symptomatic plants in the variety development program at Canal Point, and the others had appeared resistant or moderately resistant to leaf scald disease. US 59-16-1 was considered moderately susceptible to leaf scald disease and had been the standard for comparison when screening for leaf scald resistance in the variety development program prior to the recent leaf scald outbreak.

The stalks were submerged in running, cold tap water for $48 \mathrm{~h}$ followed by hot-water treatment at $50^{\circ} \mathrm{C}$ for $3 \mathrm{~h}$ to eradicate any latent infections with $X$. albilineans (38). Single-node cuttings from the stalks were propagated, and all subsequent plant material were obtained from a nursery established with the plants. The nursery was planted in the field at the Tropical Research and Education Center, Homestead, FL, which was at least $120 \mathrm{~km}$ from the nearest fields of leaf scald-affected sugarcane and approximately $1 \mathrm{~km}$ from where all experimentally inoculated plants were subsequently kept. The nursery was monitored for leaf scald symptoms and thoroughly tested before and after the study for the presence of $X$. albilineans by isolation on selective medium using the stalk-blot inoculation method (10), and evidence of leaf scald was not detected.

Plant inoculations. Prior to experiments, the pathogenicity of $X$. albilineans strains was verified by test inoculations of sugarcane. Only strains of PFGE groups A and B were used because of phytosanitary quarantine restrictions in Florida. Low-passage cultures of pathogenic strains reisolated from test plants were used for inoculum preparation in experiments. Inoculum consisted of cultures resuspended in $0.01 \mathrm{M}$ phosphate buffered saline (PBS), $\mathrm{pH} 7.0$, at $1 \times 10^{9} \mathrm{CFU} / \mathrm{ml}$. Plants were inoculated by the soak (16) or modified decapitation methods (29). In the soak method, single-node stalk cuttings were soaked in inoculum for $1 \mathrm{~h}$ prior to planting. In the decapitation method, the spindle leaves on a stalk were cut off just below the third visible dewlap with pruning shears sprayed with inoculum, and inoculum was then also sprayed onto the cut surface.

Experimental design and disease severity ratings. In the first experiment, the susceptibility of all cultivars to infection by two strains each of PFGE groups A and B was examined. Strains XACP-057 and XACP-073 of PFGE group A (subsequently determined to belong to haplotypes A-03 and A-01, respectively) and strains XACP-031 and XAFL-038 of PFGE group B (both belonging to haplotype B-01) were used. Plants mock-inoculated with PBS alone were used as controls. The primary stalk of six plants that were 8 to 14 weeks old and 12 cuttings were inoculated by the decapitation and soak methods, respectively, per treatment, and the entire experiment was repeated once after 3 months. Plants were kept outside in full sunlight in plastic pots or flats and watered as needed by hand. Attempts were made to reisolate the pathogen from the upper third of the primary stalks of all surviving plants after 24 weeks. Data were analyzed using the General Linear Models procedure of SAS.
In the second experiment, both infection frequency and leaf scald severity were examined. Plants were inoculated by the decapitation method, as described above, with strains of both PFGE groups. The cultivars were CP 72-1210, CP 75-1553, CP 81-1302, CP 81-1384, CP 84-1198, and CP 85-1308. The PFGE group A (haplotype A-01) strains were XACP-067, XACP-068, XACP073, and XACP-070. The PFGE group B (haplotype B-01) strains were XACP-031, XAFL-038, XACP-077D, and XACP-081D. Two groups of 22 plants of each cultivar that were 21 weeks old were inoculated per treatment, and the experiment was repeated once after 1 week. Plants were kept in a clear, plastic-covered house in plastic flats and watered daily by overhead sprinklers. Plants were rated for disease severity in inoculated leaves after 4 and 8 weeks, and again in newly emerged, noninoculated leaves after 8 and 22 weeks. Severity was rated by the procedure described by Rott et al. (34); briefly, the ratings for a plant were $0=$ no symptoms, $1=$ one to two chlorotic pencil stripes on leaves, $2=$ greater than two pencil stripes, 3 = bleaching or more wide-spread chlorosis of leaves, $4=$ necrosis of leaves, and $5=$ death of the plant. After the final severity rating, attempts were made to reisolate the pathogen from the upper third of the main stalk of each plant.

\section{RESULTS AND DISCUSSION}

The genetic relatedness of a total of 218 strains of $X$. albilineans from 31 geographic locations worldwide was investigated (Table 1). Following SpeI digestion of genomic DNA and PFGE of the resulting fragments, between 10 and 21 bands were observed per strain, and a total of 102 band positions were scored (Fig. 1). Fifty-four unique DNA banding patterns (haplotypes) were detected by visual inspection. Eight groups of similar haplotypes were found. These eight PFGE groups were assigned alphabetic designations from $\mathrm{A}$ to $\mathrm{H}$, and haplotypes within each group were numbered sequentially producing a unique alphanumeric designation for each haplotype (Table 1).

Principal component analysis of the similarity matrix, comprised of Dice coincidence indices between all SpeI haplotypes, was conducted to examine the genetic relationships among strains. The first three principal components accounted for 56.7, 19.8, and $12.1 \%$ of the total variance for a cumulative total of $88.6 \%$, and a three-dimensional plot of these components indicated the same groupings of haplotypes that had been previously detected by visual inspection (Fig. 2). The same groups were also identified by UPGMA analysis, and bootstrap values were at least $99.3 \%$ for the five groups with multiple haplotypes (Fig. 1). Thus, the eight groupings appeared to be robust.

Sixty-one of the 218 strains had been previously characterized on the basis of serological, whole-cell protein, and FAME properties (Table 1). The strains were divided into two groups on the basis of whole-cell protein banding patterns, and, without exception, strains in PFGE groups A, B, D, and G belonged to protein group 1, and strains in PFGE groups $\mathrm{C}, \mathrm{E}$, and $\mathrm{F}$ belonged to protein group 2. The strains had also been divided into three groups each on the basis of serological and FAME properties. The uniformity of serological properties within groups, defined by the combination of PFGE and protein profiles, was good with few exceptions. Forty-six of 47 strains of protein group 1 belonged to serovar 1. All strains belonging to protein group 2 and PFGE groups $\mathrm{C}$ and $\mathrm{F}$ belonged to serovar 2, and all strains belonging to protein group 2 and PFGE group E belonged to serovar 3. FAME properties had the least correspondence to the other properties. For example, within protein group 1, haplotype A-01 contained strains belonging to both FAME groups 1 and 3, and haplotype B01 contained strains belonging to both FAME groups 1 and 2 . Similarly, in protein group 2, haplotype D-08 also contained strains belonging to both FAME groups 1 and 2. Overall, however, PFGE groupings could not be predicted on the basis of any combination of protein, serological, or FAME properties. 
Sixty-six strains of $X$. albilineans from Florida were examined in the present study (Table 1). The protein and serological properties of the strains provided no evidence to indicate that the outbreak of leaf scald in Florida in the late 1980s was due to the introduction of a new strain, because all of the strains were the same, belonging to protein group 1 and serovar 1 . However, two distinct groups were identified among the strains based on PFGE profiles, and the spatial and temporal distribution of strains within each group strongly suggested that one group was responsible for the outbreak. Leaf scald was first reported in Florida in 1967 (22), and all 15 X. albilineans strains isolated from 1967 to 1987 prior to the outbreak belonged to PFGE group A (14 strains of haplotype A-01 and one strain of haplotype A-04) and came from sugarcane in the breeding program at the United States Sugarcane Field Station in Canal Point (XACP strains in Table 1). Fifty-one strains were isolated from 1989 to 1996 after the beginning of the outbreak, and 47 of these strains belonged to PFGE group B (46 strains of haplotype B-01 and one strain of haplotype B-03). Four strains of PFGE group A (two strains each of haplotypes A-01 and A-03) were isolated after 1988 and, like the other PFGE group A strains from Florida, were from Canal Point. Eight of the PFGE B strains (all haplotype B-01; XAFL strains in Table 1) were isolated from sugarcane in commercial production at various locations in the Everglades agricultural area of Florida, 27 of the PFGE group B strains (26 strains of haplotype B-01 and one strain of haplotype B-03) were isolated from sugarcane at Canal Point, and the exact geographic origin of the remaining 12 strains (all haplotype B-01; USA strains from Florida in Table 1) is presently unknown. Thus, the first strains of $X$. albilineans to become established in Florida belonged to PFGE group A, but their spread was limited to breeding lines at Canal Point. Subsequently, however, the outbreak in the late 1980s apparently resulted from the introduction of another strain or strains belonging to PFGE group $\mathrm{B}$, which spread both in breeding lines and commercial plantings.

Based on strains examined in this study, the recent outbreaks of leaf scald in Guadeloupe, Louisiana, Texas, and Taiwan might have also been associated with strains of PFGE group B. Moreover, the sole or most prevalent haplotype from these locations was B-01. The oldest strain examined was MTQ-032A from Martinique, isolated in 1932, and it was also found to belong to haplotype B-01. Other haplotype B-01 strains were isolated in Barbados in 1968 and St. Kitts in 1969. Furthermore, a haplotype B-17 strain was isolated in Guyana in 1949, and a haplotype B-13 strain was isolated in St. Lucia in 1957. Thus, strains of the PFGE group B had been present in the Caribbean region for many years prior to the outbreaks.

PFGE group B was the largest PFGE group, accounting for 134 $(61.5 \%)$ of the strains, and also the most widely distributed, being found in $15(55.5 \%)$ of the locations of geographic origin. PFGE group B strains were predominantly from the Western Hemisphere and might have spread more recently to the African and Asian

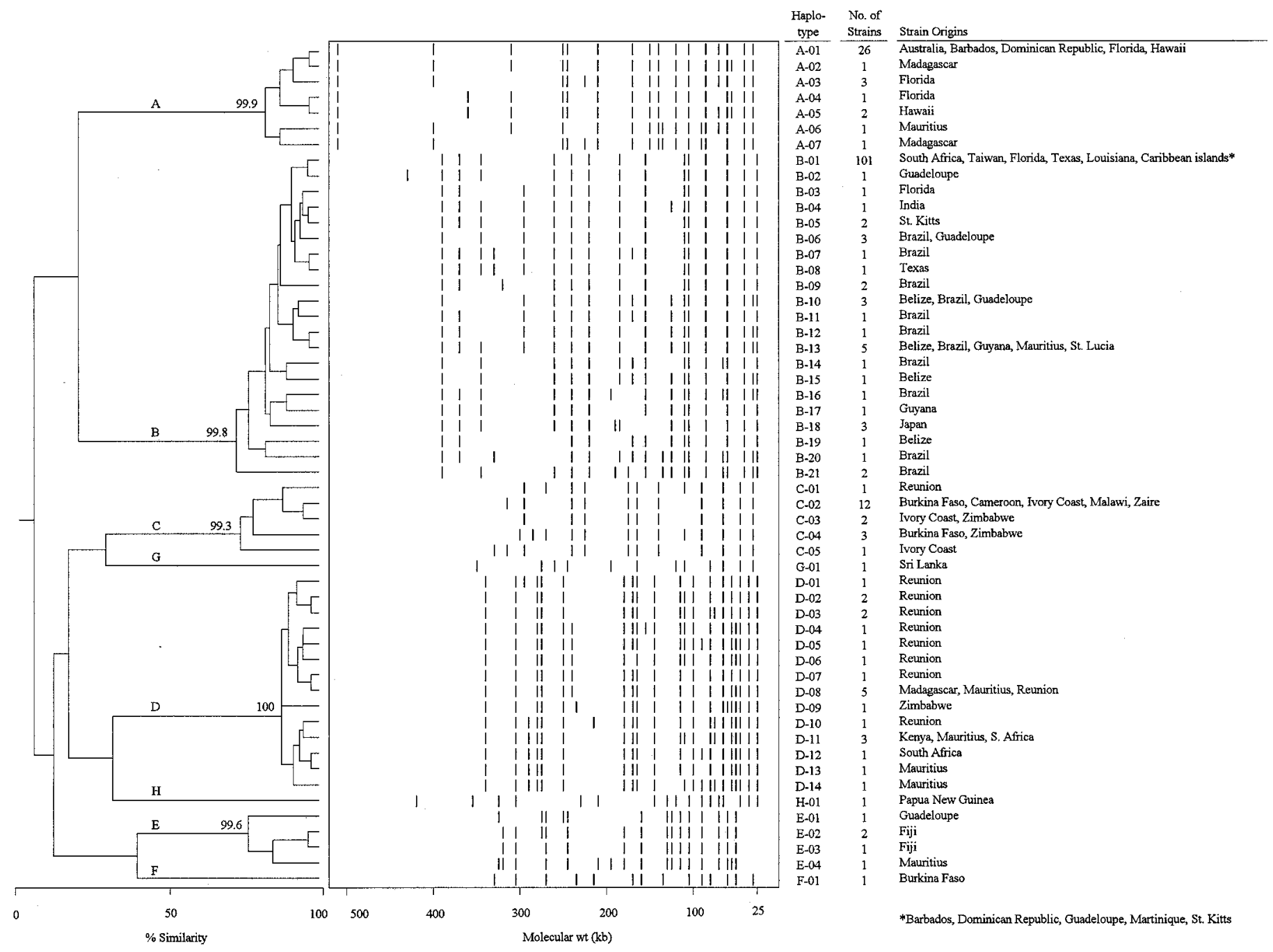

Fig. 1. Similarity among 54 haplotypes of Xanthomonas albilineans. Each haplotype represents a unique DNA banding pattern. Genomic DNA of 218 strains from 31 geographic locations was digested with SpeI, and large DNA fragments were separated by pulsed-field gel electrophoresis (PFGE). The dendrogram showing the relationship among haplotypes was derived by cluster analysis of distances between haplotypes using the unweighted pair group method with arithmetic means (UPGMA). Eight clusters were resolved at the 0.75 similarity level. The clusters were designated PFGE groups A to H, as indicated on the branches leading to each cluster. Bootstrap $P$ values are indicated at the corresponding node for each cluster. 
regions as evidenced by strains isolated in India in 1983, Japan in 1990, Taiwan in 1987, and South Africa in 1993. Interestingly, PFGE groups C and D were from Africa or the adjacent Mascarene islands, but were not found on other continents.

The existence of multiple haplotypes of the same PFGE group within a geographic area might be indicative of more than one introduction of the pathogen. However, the possibility also exists that mutation of a single introduction has given rise to more than one haplotype. In either case, a single haplotype of each PFGE group appears to predominate in some geographic locations. In Florida, for example, 16 of the $19(84.2 \%)$ PFGE group A strains belonged to haplotype A-01, and 46 of 47 (97.9\%) PFGE group B strains belonged to haplotype B-01. In other locations, however, such as Brazil and Reunion, PFGE groups B and D predominated, respectively, but a single haplotype was not predominant in either location. Over all locations, the haplotypes A-01 and B-01 also predominated within their PFGE groups. Similarly, haplotype C02 was predominant in PFGE group C. Predominant haplotypes were not apparent in the remaining PFGE groups.

Strains of $X$. albilineans from Florida belonging to PFGE groups A and B were examined for evidence of pathologically significant intraspecific variation that might help to explain the recent outbreak of leaf scald. In the initial experiment, 22 sugarcane cultivars were inoculated both by the decapitation and soak methods with two strains each of PFGE groups A and B. Results were similar when the experiment was repeated (data not shown), so data were combined for analysis. The overall reisolation rate was $16.8 \%$ for the 776 plants inoculated by the decapitation method and $1.6 \%$ for the 1,234 plants inoculated by the soak method as determined 24 weeks after inoculation. Strains XACP057 (haplotype A-03) and XACP-073 (haplotype A-01) of PFGE group A were recovered from 1.4 and $3.3 \%$ of the plants, respectively; strains XACP-031 and XAFL-038 of PFGE group B (haplotype B-01) were recovered from 4.8 and $21.0 \%$ of the plants, respectively; and the pathogen was not isolated from stalks of any of the mock-inoculated controls. A significant difference in reisolation was detected between PFGE groups $(P<0.01)$, but not between cultivars $(P>0.22)$. No PFGE group by cultivar interaction was detected with respect to reisolation, suggesting that the two PFGE groups did not represent different races of the pathogen.

A second inoculation experiment was conducted in which both disease severity and infection rate were examined. The experiment was also designed with the intention of overcoming problems associated with the low rate of infection that had been encountered in the first experiment. The cultivars used in the second experiment were selected from the cultivars examined in the first experiment on the basis of having had among the highest infection rates, as for CP 81-1384, CP 75-1553, CP 85-1308, and CP 811302 , or of having been infected by PFGE group B strains, but not by PFGE group A strains, based on reisolation results, as for $\mathrm{CP}$ 72-1210, CP 84-1198, and CP 85-1308. Only the decapitation method of inoculation was used, and the number of strains was increased to four strains each of PFGE groups A and B. Results were similar when the experiment was repeated (data not shown), so data were combined for analysis. The mean severity rating for inoculated leaves after inoculation was 0.8 at 4 weeks and 1.1 at 8 weeks. The mean severity rating for noninoculated leaves developing on inoculated plants after inoculation was 0.2 at 4 weeks and 1.0 at 8 weeks. Symptoms on inoculated leaves were present in 47.6 and $49.7 \%$ of the 1,776 inoculated plants after 4 and 8 weeks, respectively. Symptoms on noninoculated leaves were present in 11.8 and $23.3 \%$ of the plants after 8 and 22 weeks, respectively. The pathogen was reisolated from 544 (30.6\%) of the plants 22 weeks after inoculation.

However, spread of the pathogen occurred among the plants during the experiment, which invalidated analysis of effects related to different strains. When some of the reisolated strains were examined by PFGE, eight of 15 strains from plants inoculated with PFGE group A strains belonged to PFGE group B; whereas all 16 strains from plants inoculated with PFGE group B strains belonged to that group. The plants had been kept in the same house with numerous noninoculated plants. Widespread transmission to noninoculated plants became evident based on symptoms and positive isolations. Furthermore, when nonsymptomatic, noninoculated plants adjacent to symptomatic, noninoculated plants on the same bench were tested, PFGE group B strains were isolated from washes of the leaf surfaces of seven of 12 plants, but not from their internal tissues after surface disinfestation. All strains used as inoculum and subsequently recovered from plants belonged to haplotypes A-01 or B-01; therefore, it was not possible to determine by PFGE or any other method available at the time which of the individual strains had spread from plant to plant after inoculation.

Plant-to-plant spread had not been detected in the first inoculation experiment. A combination of factors might have created more favorable conditions for the inadvertent spread of the pathogen in the second experiment. During the first experiment, the plants were kept outside and watered by hand as needed; whereas, in the second experiment, the plants were kept in a clear-plastic house and watered daily by overhead sprinkler irrigation. Therefore, more free moisture might have been present on leaf surfaces for longer periods of time, possibly favoring pathogen survival and movement, and there might have been a greater chance for the pathogen to have been spread by splashing water. Furthermore, the overall susceptibility of the cultivars selected for the second experiment was probably greater.

Evidence of possible aerial spread of $X$. albilineans has been observed under field conditions in Guadeloupe (21) and Mauritius (4), where recent outbreaks of leaf scald have occurred. Such a means of transmission would be in agreement with the observation of Hoy and Grisham (18) that the spread of leaf scald was greater in areas of Louisiana more severely affected by a hurricane in 1992. All five strains from Louisiana examined in the present study belonged to haplotype B-01. It might be that some PFGE group B strains survive better epiphytically or have a greater propensity toward aerial transmission, either in aerosols or splashing water, than strains of some other PFGE groups. This, however, needs to be determined experimentally and might be a characteristic of only some strains within PFGE group B and not of PFGE group B as a whole, since that haplotype, B-01, has been in the Caribbean region for at least 50 years and yet widespread outbreaks of strains belonging to this haplotype have occurred only recently.

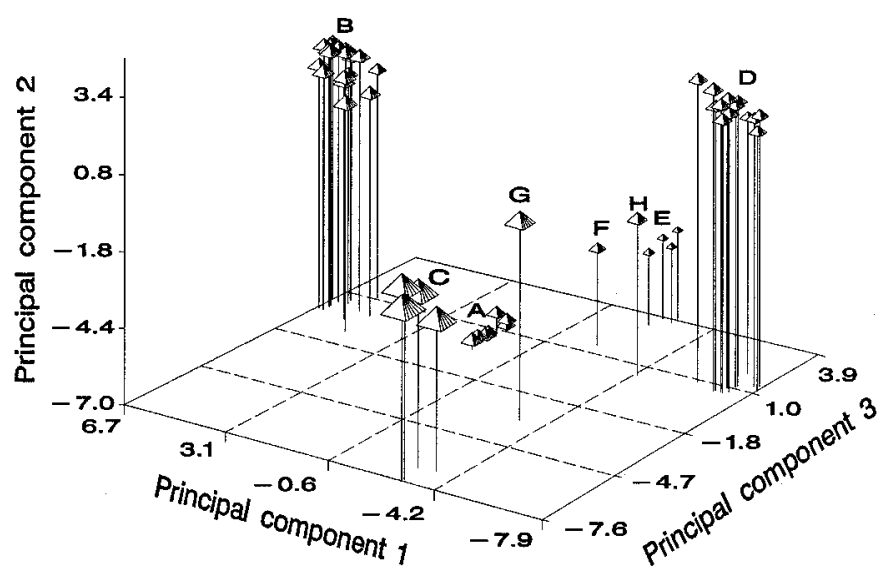

Fig. 2. Three-dimensional plot of the first three principal components obtained by analysis of Dice's coincidence indices for the pairwise comparisons of DNA bands between 54 Xanthomonas albilineans haplotypes. The haplotypes represented unique banding patterns that were obtained after genomic DNA was digested with SpeI restriction endonuclease and large DNA fragments were separated by pulsed-field gel electrophoresis (PFGE). Eight SpeI PFGE groups (A to $\mathrm{H}$ ) were detected among the haplotypes. Values are in eigenvectors. 
Further studies on the movement of PFGE group B strains, and their epiphytic and pathogenic capabilities, are needed to help understand $X$. albilineans and the threat it poses to sugarcane industries worldwide. Nevertheless, the existence of distinct genetic variants of $X$. albilineans and the limited distribution of the individual variants throughout the world reinforces the need for measures, such as quarantine regulations, to prevent the spread of the pathogen between sugarcane-growing regions.

\section{ACKNOWLEDGMENTS}

This research was supported, in part, by funds from the Florida Sugar Cane League. We thank all of our colleagues and members of the International Society of Sugar Cane Technologists who provided strains of $X$. albilineans. Florida Agricultural Experiment Stations Journal Series R05339.

\section{LITERATURE CITED}

1. Alvarez, A. M., Schenck, S., and Benedict, A. A. 1996. Differentiation of Xanthomonas albilineans strains with monoclonal antibody reaction patterns and DNA fingerprints. Plant Pathol. 45:358-366.

2. Antoine, R., and Pérombelon, M. 1965. Leaf scald. Pages 56-58 in: Mauritius Sugar Institute Annual Report. Mauritius Sugar Inst., Reduit, Mauritius.

3. Autrey, L. J. C., Saumtally, S., Dookun, A., and Médan, H. 1995. Studies on variation in the leaf scald pathogen, Xanthomonas albilineans. Proc. Int. Soc. Sugar Cane Technol. 21:485-497.

4. Autrey, L. J. C., Saumtally, S., Dookun, A., Sullivan, S., and Dhayan, S. 1995. Aerial transmission of the leaf scald pathogen, Xanthomonas albilineans. Proc. Int. Soc. Sugar Cane Technol. 21:508-526.

5. Brosch, R., Chen, J., and Luchansky, J. B. 1994. Pulsed-field fingerprinting of Listeriae: Identification of genomic divisions for Listeria monocytogenes and their correlation with serovar. Appl. Environ. Microbiol. 60:2584-2592.

6. Chen, C. T., Lin, C. P., and Liang, Y. G. 1993. Leaf scald of sugarcane in Taiwan. Taiwan Sugar 40:8-16.

7. Comstock, J. C., Miller, J. D., and Tai, P. Y. P. 1995. Changes in leaf scald incidence in the Canal Point sugarcane cultivar development program in Florida: 1987-1993. J. Am. Soc. Sugar Cane Technol. 15:54-60.

8. Comstock, J. C., and Shine, J. M., Jr. 1992. Outbreak of leaf scald of sugarcane, caused by Xanthomonas albilineans, in Florida. Plant Dis. 76:426.

9. Davis, M. J. 1992. Increased incidence of leaf scald disease in Florida associated with a genetic variant of Xanthomonas albilineans. Sugar Azucar 87(6):34.

10. Davis, M. J., Rott, P., Baudin, P., and Dean, J. L. 1994. Evaluation of selective media and immunoassays for detection of Xanthomonas albilineans, causal agent of sugarcane leaf scald disease. Plant Dis. 78:7882.

11. Dice, L. R. 1945. Measures of the amount of ecologic association between species. Ecology 26:297-302.

12. Egel, D. S., Graham, J. H., and Stall, R. E. 1991. Genomic relatedness of Xanthomonas campestris strains causing diseases of citrus. Appl. Environ. Microbiol. 57:2724-2730.

13. Frey, P., Smith, J. L., Albar, L., Prior, P., Saddler, G. S., Trigalet-Dimery, D., and Trigalet, A. 1996. Bacteriocin typing of Burkholderia (Pseudomonas) solanacearum race 1 of the French West Indies and correlation with genomic variation of the pathogen. Appl. Environ. Microbiol. 62:473-479.

14. Gordillo, M. E., Singh, K. V., and Murray, B. E. 1993. Comparison of ribotyping and pulsed-field gel electrophoresis for subspecies differentiation of strains of Enterococcus faeclis. J. Clin. Microbiol. 31:15701574.

15. Grisham, M. P., Legendre, B. L., and Comstock, J. C. 1993. First report of leaf scald, caused by Xanthomonas albilineans, of sugarcane in Louisiana. Plant Dis. 77:537.

16. Harrison, N. A., Davis, M. J., and Dean, J. L. 1986. Infectivity titrations of Clavibacter xyli subsp. xyli and sugarcane cultivars differing in susceptibility to ratoon stunting disease. Plant Dis. 70:556-558.

17. Herrmann, J. L., Bellenger, E., Perolat, P., Baranton, G., and Saint Girons, I. 1992. Pulsed-field gel electrophoresis of NotI digests of lep- tospiral DNA: A rapid new method of serovar identification. J. Clin. Microbiol. 30:1696-1702.

18. Hoy, J. W., and Grisham, M. P. 1994. Sugarcane leaf scald distribution, symptomatology, and effect on yield in Louisiana. Plant Dis. 78:10831087.

19. Irvine, J. E., Amador, J. M., Gallo R., M. I., Riess, C. M., and Comstock, J. C. 1993. First report of leaf scald, caused by Xanthomonas albilineans, of sugarcane in Mexico. Plant Dis. 77:846.

20. Isakeit, T., and Irvine, J. E. 1995. First report of leaf scald, caused by Xanthomonas albilineans, of sugarcane in Texas. Plant Dis. 79:860.

21. Klett, P., and Rott, P. 1994. Inoculum sources for the spread of leaf scald disease of sugarcane caused by Xanthomonas albilineans in Guadeloupe. J. Phytopathol. 142:283-291.

22. Koike, H. 1968. Leaf scald of sugarcane in continental United States-A first report. Plant Dis. Rep. 52:646-649.

23. Martin, J. P., and Robinson, P. E. 1961. Leaf scald. Pages 79-107 in: Sugarcane Diseases of the World, Vol. 1. J. P. Martin, E. V. Abbott, and C. G. Hughes, eds. Elsevier Publishing Co., Amsterdam.

24. North, D. S. 1926. Leaf Scald, a Bacterial Disease of Sugarcane. Agric. Rep. No. 8. Colonial Sugar Refining Co., Ltd., Sydney, Australia.

25. Ovalle, W., Comstock, J., Juarez, J., and Soto, G. 1995. First report of leaf scald of sugarcane (Xanthomonas albilineans) in Guatemala. Plant Dis. 79:212.

26. Persley, G. J. 1973. Pathogenic variation in Xanthomonas albilineans (Ashby) Dowson, the causal agent of leaf scald disease of sugarcane. Aust. J. Biol. Sci. 26:781-788.

27. Prévost, G., Jaulhac, B., and Piémont, Y. 1992. DNA fingerprinting by pulsed-field gel electrophoresis is more effective than ribotyping in distinguishing among methicillin-resistant Staphylococcus aureus isolates. J. Clin. Microbiol. 30:967-973.

28. Ricaud, C., and Ryan, C. C. 1989. Leaf scald. Pages 39-58 in: Diseases of Sugarcane. C. Ricaud, B. T. Ryan, A. G. Gillaspie, Jr., and C. G. Hughes, eds. Elsevier Publishing Co., Amsterdam.

29. Rott, P., Abel, M., Soupa, D., Feldmann, P., and Letourmy, P. 1994. Population dynamics of Xanthomonas albilineans in sugarcane plants as determined with an antibiotic-resistant mutant. Plant Dis. 78:241-247.

30. Rott, P., Arnaud, M., and Baudin, P. 1986. Serological and lysotypical variability of Xanthomonas albilineans (Ashby) Dowson, causal agent of sugarcane leaf scald disease. J. Phytopathol. 116:201-211.

31. Rott, P., Chatenet, M., and Baudin, P. 1988. L'échaudure des feuilles de canne à sucre provoquée par Xanthomonas albilineans (Ashby) Dowson. I Synthèse bibliographique. Agron. Trop. 43:236-243.

32. Rott, P., Davis, M. J., and Baudin, P. 1994. Serological variability in Xanthomonas albilineans, causal agent of leaf scald disease of sugarcane. Plant Pathol. 43:344-349.

33. Rott, P., and Feldman, P. 1991. Les maladies de la canne à sucre en Guadeloupe: Situation actuelle et méthodes de lutte mises en place. Pages 90-94 in: Rencontres Internationales en Langue Française sur la Canne à Sucre. Association Française de la Canne à Sucre, Nogent-sur-Mame, France.

34. Rott, P., Soupa, D., Brunet, Y., Feldmann, P., and Letourmy, P. 1995. Leaf scald (Xanthomonas albilineans) incidence and its effect on yield in seven sugarcane cultivars in Guadeloupe. Plant Pathol. 44:1075-1084.

35. Skov, M. N., Pederson, K., and Larsen, J. L. 1995. Comparison of pulsed-field gel electrophoresis, ribotyping, and plasmid profiling for typing of Vibrio anguillarum serovar O1. Appl. Environ. Microbiol. 61:1540-1545

36. Sneath, P. H. A., and Sokal, R. R. 1973. Numerical Taxonomy: The Principles and Practice of Numerical Classification. W. H. Freeman and Co., San Francisco.

37. Spence, J. A. 1957. The incidence of leaf scald disease of sugarcane in the West Indies. Proc. Meet. Br. West Indies Sugar Technol. 57:140-146.

38. Steindl, D. R. L. 1971. The elimination of leaf scald from infected plant material. Proc. Int. Soc. Sugar Cane Technol. 14:925-929.

39. van den Mooter, M., and Swings, J. 1990. Numerical analysis of 295 phenotypic features of 266 Xanthomonas strains and related strains and an improved taxonomy of the genus. Int. J. Syst. Bacteriol. 40:348-369.

40. Vauterin, L., Hoste, B., Kersters, K., and Swings, J. 1995. Reclassification of Xanthomonas. Int. J. Syst. Bacteriol. 45:472-489.

41. Wilbrink, G. 1920. De Gomziekte van het Suikerriet, hare Oorzaak en hare Bestrijding. Arch. Suikerind. Ned. Indie 28:1399-1525.

42. Yang, P., Rott, P., Vauterin, L., Hoste, B., Baudin, P., Kersters, K., and Swings, J. 1993. Intraspecific variability of Xanthomonas albilineans. Syst. Appl. Microbiol. 16:420-426. 